\title{
The Influence of Microbial Consortium in Bioremediation Process Using Bioreactor
}

\author{
Nur Hidayatul Alami ${ }^{1}$, Ummu Mu'minah Shoraya ${ }^{2}$, Fatimah $^{3}$, Nimatuzahroh $^{4}$
}

\begin{abstract}
- bioreactor is one of ex situ bioremediation technologies that can be applied to solve the problem of oil contaminated soil. Bioremediation process can be enhanced by using microbial consortium that has specific characteristics to degrade the contaminant. The aim of this research was to know the effect of various concentrations of microbial consortium and incubation time on bioremediation of crude oil contaminated soil by using a bioreactor. The influence of microbial consortium concentration and incubation time in bioremediation could be known from increasing of total heterotrophic microbial and decreasing of oil residue ( $\mathrm{g} /$ g-soil). The type of the research was experimental with 1 control (without microbial consortium adding) and 3 treatments, including microbial consortium concentration of $2.5 \%(\mathrm{~K} 1), 5 \%(\mathrm{~K} 2)$, and $7.5 \%(\mathrm{~K} 3)$. The incubation times were $0-4$ weeks. The resulted data of total heterotrophic microbial were analyzed descriptively, and the resulted data of crude oil residue ( $\mathrm{g} / \mathrm{g}$-soil) were analyzed descriptively and statistically by one-way analysis of variances (one-way ANOVA) and Duncan test $(\mathrm{p}=0.05)$. The results of this research indicated concentrations of microbial consortium and incubation time affected bioremediation process in a bioreactor. K1 (2.5\%) was known to be the most effective to decrease oil residue up to $7 \%$, if compared with the control at 2 weeks of incubation time.
\end{abstract}

\section{Keywords - bioremediation, microbial consortium, incubation time, bioreactor, crude oil residue}

Abtrak - bioreaktor adalah salah satu teknologi bioremediasi eksitu yang dapat diaplikasikan untuk mengatasi permasalahan tanah tercemar minyak. Proses bioremediasi dapat ditingkatkan dengan menggunakan konsorsium mikroba yang memiliki karakteristik spesifik untuk mendegradasi pencemar. Tujuan penelitian ini adalah untuk mengetahui pengaruh berbagai konsentrasi konsorsium mikroba dan waktu inkubasi dalam bioremediasi tanah tercemar minyak mentah dengan menggunakan bioreaktor. Pengaruh konsorsium mikroba dalam bioremediasi dapat diketahui dari kenaikan total mikroba heterotrophik dan penurunan residu minyak ( $\mathrm{g}$ / g-tanah). Jenis penelitian ini adalah eksperimental dengan 1 kontrol (tanpa penambahan konsorsium mikroba) dan 3 perlakuan, termasuk konsentrasi konsorsium mikroba 2,5\% (K1), 5\% (K2), dan 7,5\% (K3). Waktu inkubasi adalah 0-4 minggu. Data hasil total mikroba heterotrofik dianalisis secara deskriptif dan data hasil residu minyak mentah (g / g-tanah) dianalisis secara deskriptif dan statistik dengan analisis variansi satu arah (one-way ANOVA) dan uji Duncan ( $\mathrm{p}=0,05)$. Hasil penelitian ini menunjukkan konsentrasi konsorsium mikroba mempengaruhi proses bioremediasi dalam bioreaktor. K1 (2,5\%) diketahui paling efektif menurunkan residu minyak hingga 7\%, bila dibandingkan dengan kontrol pada waktu inkubasi 2 minggu.

Kata Kunci-bioremediasi, konsorsium mikroba, waktu inkubasi, bioreaktor, residu minyak mentah

\section{INTRODUCTION ${ }^{1}$}

$\mathrm{N}$ owadays, bioremediation has been developed to solve the problems of oil-contaminated soil. Bioremediation is the naturally occurring process by which micro-organisms transform environmental contaminants into harmless end-products, in order to obtain the sources of carbon and energy. One of ex situ bioremediation technology is using bioreactor. The principle of bioremediation by using bioreactor is to remove the oil from contaminated soil to the certain reactor with optimization of environmental parameters such as temperature, $\mathrm{pH}$, oxygen and moisture content, these to achieve accelerated biodegradation [2] [1].

The use of bioreactors becomes an even more promising alternative, particularly for tropical soil contamination,due to the limited applicability of other classical bioremediation techniques (for instance soil washing and biopiles) for that type of soil. These methods generally provide poor mixing systems to deal with low permeability soil, hindering the incorporation of oxygen and nutrients for the biodegradation process to occur. When bioreactor is used for treatment, this problem is

\footnotetext{
${ }^{1}$ Department of Biology, Institut Teknologi Sepuluh Nopember, Surabaya, Indonesia, E-mail: Nh_daya@yahoo.com

${ }^{2}$ Department of Biology, Universitas Airlangga, Surabaya, Indonesia

${ }^{3}$ Department of Biology, Universitas Airlangga, Surabaya, Indonesia
}

overcome through efficient homogenisation and aeration systems [8].

Degrading pollutants by microbes in bioreactors becomes a focus over the last decade. Oil degrading microbes could be come from indigenous microbes that found in contaminated soil then was stimulated by nutrients, best conditions of other chemical, physical and biological factor (biostimulation), or additions of oiloxidizing microbes that was isolated from other sites (bioaugmentation) [1].

The presence of crude oil degrading microbes is expected to reduce levels of pollutants up to a safe level. In addition, by using microbes in the degradation is more environmentally friendly, effective, and more economical.

In previous research, it has successfully formulated microbial consortium based on the ability of each isolate to grow in the substrate of crude oil, diesel fuel, and lubricating oil, and tested for their ability to degrade diesel in liquid culture [5].

The ability of microbes to degrade crude oil pollutants is influenced by several factors, including the microbial concentration and incubation time. 
Based on the sentences above, it is necessary to study the effect of the concentration of crude oil-degrading microbes and the incubation time in bioremediation process using bioreactor on this research.

\section{METHOD}

\section{A. Microbial isolates}

Oil-degrading microbes used in this study was obtained from Microbiology Laboratory, Biology Department, Airlangga University, Surabaya. The bacterial isolate was maintained on nutrient agar (NA), while yeast isolate was on Sabouroud Dextrose Agar (SDA).

\section{B. Preparation of Bioreactor}

Bioreactor was made of polyacrilic with dimensions of a length of $20 \mathrm{~cm}$, width of $20 \mathrm{~cm}$, and $30 \mathrm{~cm}$ high or 20 L x $20 \mathrm{~W}$ x $30 \mathrm{H}$. The lower part of bioreactor was equipped with shelters leachate as high as $5 \mathrm{~cm}$ from the total of the high. Shelter leachate and soil substrate were bounded by filter which water could pass but did not pass the substrate (mess \pm 100 ). 4 holes on the outer side of the bioreactor were provided to take samples. Bioreactors were connected with aeration pump (compressor) which served blowing air through the pipes that was strung on the bioreactor. A schematic diagram of the bioreactor is shown in Figure 1 as followed.

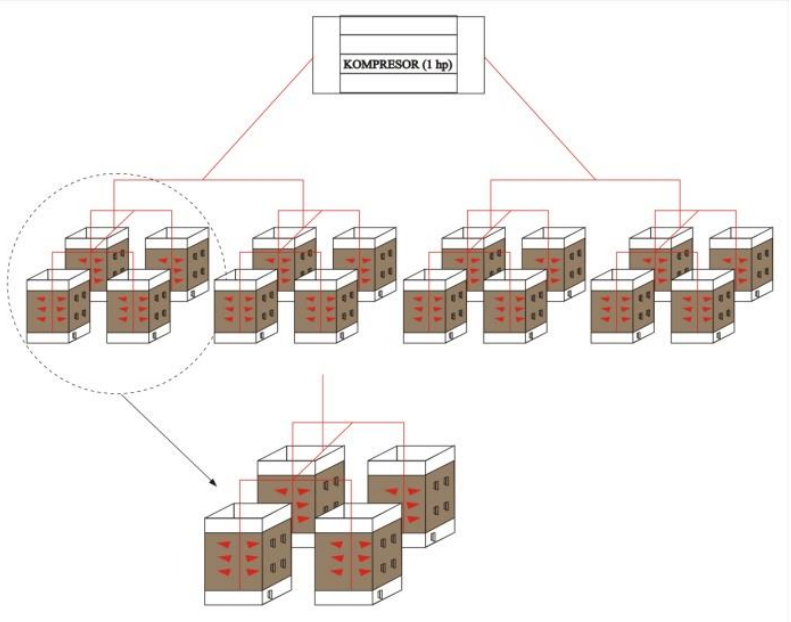

Figure 1. A schematic diagram of bioreactor

\section{Soil, nutrition, and crude oil preparation}

In this research 4 bioreactors were used, in which each bioreactor contained a mixture of $12 \mathrm{~kg}$ of soil substrate, nutrients $159.96 \mathrm{~g}, 345 \mathrm{ml}(2.5 \%)$ of crude oil, and microbial consortium. The amount of nutrients was introduced to crude oil in order to obtain a $\mathrm{C}: \mathrm{N}$ ratio of 100: 10 .

\section{Inoculums preparation}

The concentrations of microbial consortium used were 3 types, that were: the concentration of $1(2.5 \%)$, the concentration of $2(5 \%)$, and the concentration of 3 $(7.5 \%)$. The addition of microbial consortium were 300 $\mathrm{ml}, 600 \mathrm{ml}$, and $900 \mathrm{ml}$ for each concentration of 1,2, and 3 on the $\mathrm{A} 600 \mathrm{~nm}=0.6$ in $12 \mathrm{~kg}$ of soil substrate.

\section{E. Bioremediation experiment}

\section{Preparing 4 bioreactors}

The soil substrate was mixed with nutrients and crude oil that had been previously prepared with $300 \mathrm{ml}$ of microbial consortium to a concentration of $1,600 \mathrm{ml}$ of microbial consortium to a concentration of 2, and $900 \mathrm{ml}$ of microbial consortium to a concentration of 3 . For each bioreactor consists of a mixture of substrate soil, nutrients, crude oil, and microbial consortium according to the treatment concentration. Then, a mixture of soil substrate, crude oil, nutrients, and concentration of microbial consortia was filled into each bioreactor (R), with the following details:

R1: soil substrate + crude oil + nutrients $(\mathrm{K} 0 /$ control $)$

$\mathrm{R} 2$ : soil substrate + crude + nutrition $+\mathrm{K} 1$

R3: soil substrate + crude + nutrition $+\mathrm{K} 2$

R4: soil substrate + crude + nutrition $+\mathrm{K} 3$

Each bioreactor was divided into two sampling areas (as replicates). The soil moisture was set in the bioreactor to $70-80 \%$ by adding water using a sprayer. The soil substrate was incubated for 4 weeks. Every week (M0, M1, M2, M3, and M4) samples were taken for TPC and oil residue. Aeration was conducted twice a day by turning on the compressor for 2 hours on a single aeration and maintained soil moisture by adding water using a sprayer twice a week.

\section{F. Biodegradation measurement \\ Heterotrophic microbial calculation}

The soil samples were taken from each sampling area in each bioreactor treatment. Sampling was carried out from two sampling sites in each area using a bioreactor sampling pipe with a diameter of $1.5 \mathrm{~cm}$. Sampling was conducted in accordance with incubation time that was determined. Then, soil obtained from two sampling sites in each sampling area in the bioreactor according to treatment were homogenized. $10 \mathrm{~g}$ of soil sample homogenized was taken, then the soil was filled into each $250 \mathrm{ml}$ of bottles containing $90 \mathrm{ml}$ of sterile physiological water ( 1 sample $(10 \mathrm{~g}) \times 8$ treatments $=8$ bottles $)$. Samples were stirred using a vortex until homogeneous and then precipitated for 5-10 minutes. After 5-10 minutes, $1 \mathrm{ml}$ of the soil suspension was taken from each treatment bottle and was put into a test tube, that contained $9 \mathrm{ml}$ of sterile physiological water and then done a series of dilutions (10 ${ }^{1}, 10^{-2}, 10^{-3}$, and so on according needs). After that, the suspension was cultured with pour plate method.

\section{Total Petroleum Hydrocarbon (TPH) analysis}

Soil samples were taken from each sampling area in each bioreactor treatment. Sampling was carried out from two sampling sites in each area using a bioreactor sampling pipe with a diameter of $1.5 \mathrm{~cm}$. Sampling was conducted in accordance to incubation time that was determined. Soil was obtained from two sampling sites in each sampling area. $10 \mathrm{~g}$ of soil sample that has been homogenized was taken. The soil was filled in each 100 $\mathrm{ml}$ of bottle ( 1 sample $(10 \mathrm{~g})$ x 8 treatments $=8$ bottles $)$. At the end of incubation time, the soil in a bottle treatment was dried for oil residue analysis by puting it in the oven with a temperature of $\pm 75^{\circ} \mathrm{C}$ for \pm 3 days. After that, the dried soil was grinded. One gram of grinded soil was then added into the tube, $5 \mathrm{ml}$ of toluene was added and was 
homogenized with vortex for \pm 10 seconds, then was left for 10 minutes. Supernatant then was separated from soil precipitation using Whatman filter paper no. 1 that were placed in a glass funnel and collected in a clean, dry glass bottle. Supernatant was diluted for 2 times by means of : $2 \mathrm{ml}$ of the supernatant from filtration was filled in cuvettes tube, $2 \mathrm{ml}$ of toluene was added and then OD value was measured by spectrophotometer at $\lambda=420 \mathrm{~nm}$. The result of measurement were then calculated into standard curve, so that will be obtained crude oil content $(\mathrm{mL} / \mathrm{g}$ tanah), then was converted into $\mathrm{g} / \mathrm{g}$ soil [7].

\section{RESULTS AND DISCUSSION}

Influence of microbial consortia in bioremediation of oil contaminated soil using a bioreactor, can be seen from increasing of total heterotrophic microbial and decreasing of oil residue ( $\mathrm{g} / \mathrm{g}$-soil). Total heterotrophic microbial with various concentrations $(0 \%, 2.5 \%, 5 \%$, and $7.5 \%)$ is shown in Figure 2.

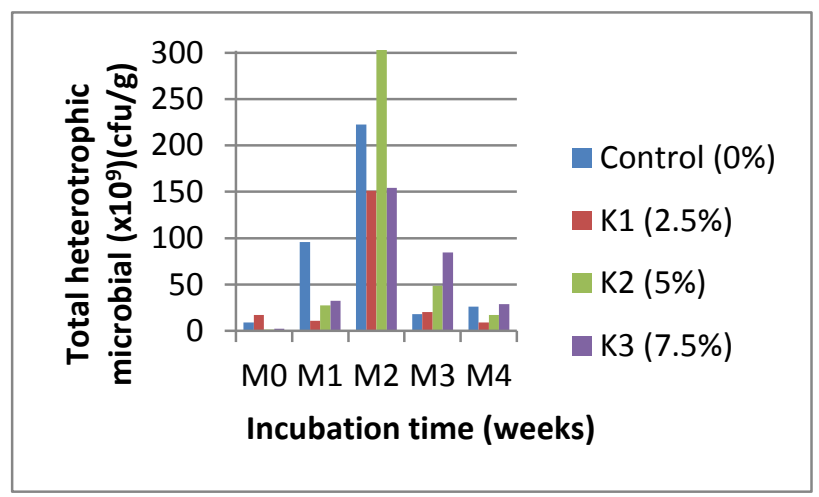

Figure 2. Total heterotrophic microbial $\left(\times 10^{9}\right)(\mathrm{cfu} / \mathrm{g})$ of each concentration $(0 \%, 2.5 \%, 5 \%$, and $7.5 \%)$ during incubation time $(0$ week, 1 week, 2 weeks, 3 weeks, and 4 weeks)

The results show that total heterotrophic microbes increased during incubation time up to second week. The highest count of total heterotrophic microbes was obtained in the second week. The increasing of heterotrophic microbes may because of the availability of $\mathrm{C}$ substrate that was obtained by microbial activity during 0 week up to second week. In this study, the soil still contained indegenous microbes. So, it was still found microbial growth in the control. Negative interactions between indegenous microorganisms and augmented microorganisms could possibly occur. This was resulting in fluctuation of total microbial between treatments. So that, the effectiveness of microbial added on bioremediation process still remains to be seen from the data of crude oil residue. The reduction in population of microbes after 2 weeks of incubation time could be due to the fact that the organisms have exhausted the available nutrient supplies present in the system. It could also be that mineralization of hydrocarbons could have possibly resulted in the production of toxic metabolites which on introduction into the system reduces the growth phase of the microbes. Many research reported that microbial growth population was also influenced by several environmental factors, such as: $\mathrm{pH}$, moisture, and availability of oxygen [10].

The result of total petroleum hydrocarbons with various concentrations $(0 \%, 2.5 \%, 5 \%$, and $7.5 \%)$ is shown in Figure 3.

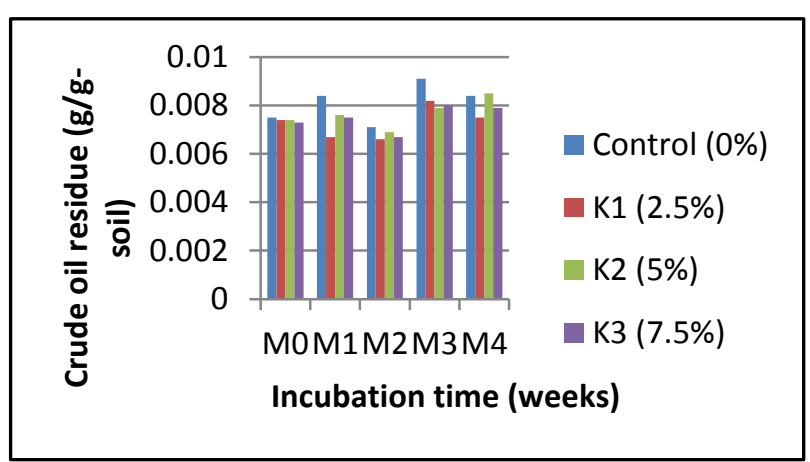

Figure 3. Crude oil residue (g/g-soil) of each concentration $(0 \%, 2.5 \%$, $5 \%$, and $7.5 \%$ ) during incubation time ( 0 week, 1 week, 2 weeks, 3 weeks, and 4 weeks)

Figure 3 shows that the interaction between variations in the concentration of microbial consortia and incubation time affected the value of crude oil residue ( $\mathrm{g} / \mathrm{g}$-soil) which was varied when compared with the control (incubation time-0). Average of crude oil residue in each treatment was lower than that of the control in every week. The lowest level of residual crude oil was obtained in the 2nd week of incubation by the K1 with a decrease of $7 \%$.

Statistical analysis showed that there was interaction effect between the variation of the concentration of microbial consortium and the incubation time on the decreasing of crude oil residue ( $\mathrm{g} / \mathrm{g}$-soil).

This means that the addition of oil degrading microbes affected reduction of crude oil residue ( $\mathrm{g} / \mathrm{g}$-soil) in a certain incubation time.

Average of crude oil residue in each treatment was lower than that of the control in every week. The lowest level of residual crude oil was obtained in the 2 nd week of incubation by the $\mathrm{K} 1$ with a decrease of $7 \%$. This is possible because the numbers of bacteria and yeast that can survive are capable of using crude oil as a carbon source.

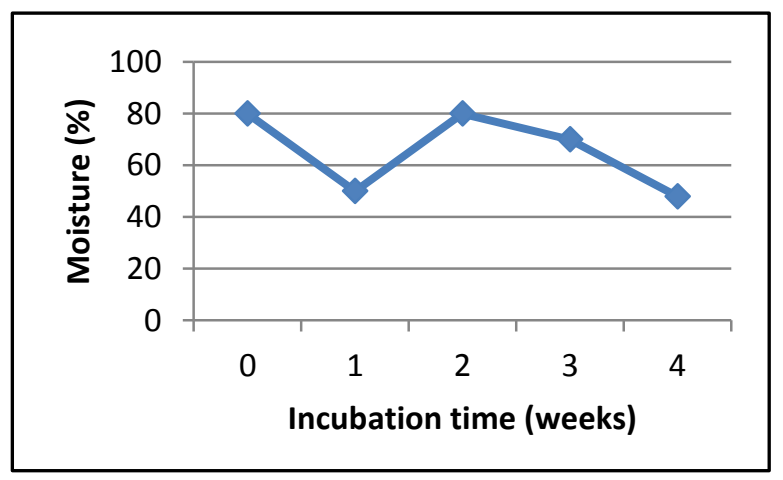

Figure 4. Moisture percentage of treatment soil during incubation time ( 0 week, 1 week, 2 weeks, 3 weeks, and 4 weeks)

In this study, the $\mathrm{K} 1$ is optimal concentration to degrade crude oil compared with others concentration. This strongly supports the process of bioremediation on a larger scale, because K1 is considered more effective in lowering the levels of residual crude oil.

Soil moisture was measured every week using a soil tester. In Figure 4 shows that the spraying at 0 week and 2 weeks led to increased humidity values. However, at week 1, 3 and 4 which the week is not do spraying, soil moisture tends to decrease. At week 4 , the humidity has decreased to $32 \%$ from $80 \%$ at week 0 to $48 \%$ at week 4 . 
Figure 5 shows $\mathrm{pH}$ graph of treated soil with the same fluctuation pattern as moisture graphs. That is because spraying with distilled water to maintain moisture in the soil also affects increasing of $\mathrm{pH}$ value. As soil moisture at week 4, $\mathrm{pH}$ of the soil decreased drastically from $\mathrm{pH} 7$ at week 0 to 3.6 at week 4 .

Water is needed by microbes because it is the largest constituent of the cell cytoplasm. Therefore, soil moisture is maintained in the range of $60-80 \%$ due to soil microbes require sufficient moisture to grow [6].

Figure 5 shows a decrease in the $\mathrm{pH}$ of the soil due to lower soil moisture. The decrease in the $\mathrm{pH}$ of the soil occurred as the result of bacterial metabolism in the form of organic acids and inorganic acids. $\mathrm{pH}$ also affect the activity of the enzyme in which the activity of the enzyme has an optimum $\mathrm{pH}$ range, if too extreme then the enzymes will be denatured. This decrease in $\mathrm{pH}$ affects the growth of bacteria because bacteria have an optimum $\mathrm{pH}$ range of about $\mathrm{pH}$ 6.5-7.5. Below $\mathrm{pH} 5$ and above 8.5, the bacteria cannot grow well unless the bacteria resistant to acid and alkaline [4].

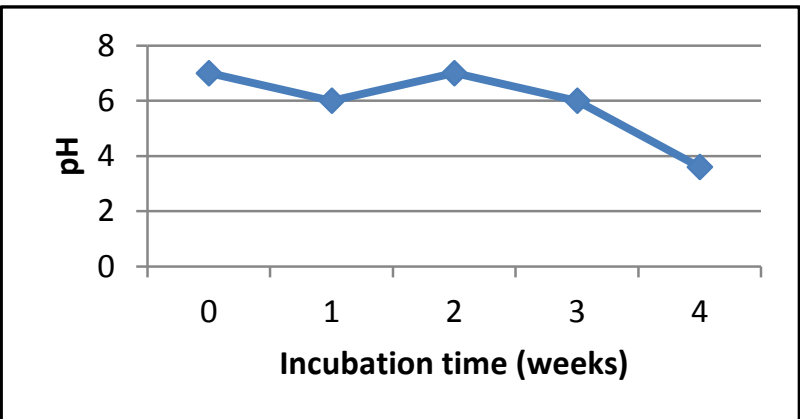

Figure 5. $\mathrm{pH}$ of treatment soil during incubation time ( 0 week, 1 week, 2 weeks, 3 weeks, and 4 weeks)

On the other hand, the availability of oxygen is another environmental factor that is important in the biodegradation of oil [6]. Aeration is one way to provide oxygen for the microbes. Aeration process can be done by reversal or by injecting oxygen into the pile of contaminated soil were processed.

This study used a bioreactor system to regulate environmental conditions. Aeration was done through pipes embedded in the ground where the air exhaled by the compressor. Soil treatments used in this study was a mixture of garden soil with sand as a bulking agent.

In this study, degradation process was less optimal, it was possible because of fluctuation of soil moisture as well as the $\mathrm{pH}$ of the soil so that it could not support optimal microbial bioremediation of oil in the process.

Some works reported that microbes inoculation had no positive,or only marginal effects on hydrocarbon biodegradation rates. Microorganisms were able to degrade organic pollutants in cultures may fail to function when inoculated into natural environments, because they might be susceptible to toxins or predators in the environment. They might use other organic compounds in preference to the pollutant, or they might be unable to move through the soil to the contaminated site. Physical adsorption to soil particles or filtration through small pores may limit the transport of organisms [3] [9].The improvement of biodegradation process in this bioreactor is needed to be done with regulate environmental factors, such as aeration, $\mathrm{pH}$, and moisture.

\section{CONCLUSIONS}

Concentrations of microbial consortium and incubation time affected on the bioremediation process in a bioreactor. K1 $(2.5 \%)$ was known to be the most effective to decrease oil residue up to $7 \%$, if compared with the control at 2 weeks of incubation time.

\section{ACKNOWLEDGMENTS}

The authors would like to thank Airlangga University for the facilities support.

\section{REFERENCES}

[1] S. Abdulsalam, I. B. S.S. Adefila and S. Ibrahim, "Bioremediation of Soil Contaminated With Used Motor Oil in a Closed System," Bioremed Biodeg, vol. 3, pp. 1-7, 2012.

[2] I. Gonzalez, F. Fava and H. M. Poggi-Varaldo, "A review on Slurry Bioreactors for Bioremediation of Soils and Sediments," Microbial Cell Factories, vol. 7: , no. 5, pp. 1-16, 2008.

[3] M. A.P., A. Paula, D. d. Franceschi and D. M. Bonotto1, "Laboratory Study on The Bioremediation of Diesel Oil Contaminated Soil from Petrol Station," Brazilian Journal of Microbiology, vol. 38, pp. 346-353.

[4] H. Mulyono, "Hidrokarbon di dalam Lingkungan Perairan. Penelitian dan Pengembangan Teknologi Minyak dan Gas Bumi," Lemigas, Jakarta, 1991.

[5] Ni'matuzahroh, Fatimah, A. Supriyanto and M. Affandi, "Bioremediasi Tanah Tercemar MenggunakanKonsorsium Mikroba," Lembaga Penelitian Universitas Airlangga, Surabaya, 2009.

[6] A. Nugroho, Bioremediasi Hidrokarbon Minyak Bumi, Yogyakarta: Graha Ilmu, 2006.

[7] J. C. Okolo, E. N. Amadi and C. T. I. Odu, "Effects of Soil Treatments Containing Poultry Manure on Crude Oil Degradation in a Sandy Loam Soil," Applied Ecology and Environmental Research, vol. 3 , no. 1, pp. 47-53, 2005.

[8] A. C. L. Rizzo, R. M. D. Santos, R. L. C. D. Santos, A. Soriano, C. A. d. Cunha, A.S.Rosado, L. S.Sobral and S. Leite, "PetroleumContaminated Soil Remediation in a New Solid Phase Bioreactor," Chem Technol Biotechnol, vol. 85, pp. 1260-1267, 2010.

[9] M. Vidali, "Bioremediation. An overview," Pure Appl. Chem., vol. 73, no. 7, p. 1163-1172, 2001.

[10] A. Vincent, E. Felix, M. Weltime, O. Ize-Iyamu and E. Daniel, "Microbial Degradation and its Kinetics on Crude Oil Polluted Soil," Research Journal of Chemical Sciences, vol. 1, no. 6, pp. 8-14, 2011. 